\title{
TANGGUNG JAWAB PELAKU USAHA JASA LAUNDRY MENURUT UNDANG-UNDANG NOMOR 8 TAHUN 1999 TENTANG PERLINDUNGAN KONSUMEN
}

\author{
Oleh : Joejoen Tjahjani, SH, MH
}

\begin{abstract}
Abstrak
Semakin maraknya pelaku usaha jasa laundry yang mendirikan usahanya tanpa adanya landasan hukum yang jelas sesuai dengan Undang-Undang Perlindungan Konsumen, maka hal ini membuat perbuatan pelaku usaha tersebut menjadi menarik untuk dibahas atau di kaji sesuai dengan undang-undang yang berlaku. Skripsi ini ditulis dengan menggunakan pendekatan normatif, dengan sumber bahan hukum primer Undang-Undang Nomor 8 Tahun 1999 tentang Perlindungan Konsumen, Undang-Undang Nomor 7 Tahun 2014 tentang Perdagangan Pasal 24, Kitab Undang-Undang Hukum Pidana Pasal 382, Kitab Undang-Undang Hukum Perdata Pasal $1244,1365,1865$, yang diperkaya dari bahan hukum sekunder berupa literatur-literatur terkait baik yang berasal dari buku maupun yang berasal dari internet.

Dari hasil study yang dilakukan penulis, didapatkan kesimpulan bahwa tanggung jawab pelaku usaha adalah ganti rugi atas perbuatan yang dilakukan pelaku usaha dengan merusak atau menghilangkan barang konsumen. Dalam upaya mengganti barang yang dirusakkan atau dihilangkan, pelaku usaha harus membayar sesuai harga barang tersebut. Karena tanggung jawab pelaku usaha sudah diatur dalam Pasal 19 Undang-Undang Perlindungan Konsumen. Pelaku usaha tidak dapat menghindar dari aturan yang sudah ditetapkan oleh undang-undang. Apabila pelaku usaha menghindar dari perbuatan tersebut, maka pelaku usaha dapat dikenakan sanksi berdasarkan hukum perlindungan konsumen. Sanksi-sanksi tersebut merupakan sanksi administrasi yaitu pelaku usaha wajib membayar denda yang sudah ditetapkan dan izin usaha tersebut akan dicabut oleh BPSK (Badan Penyelesaian Sengketa Konsumen). Sanksi perdatanya adalah pelaku usaha harus mengganti dalam bentuk pengembalian uang, penggantian barang, perawatan kesehatan, pemberian santunan, dan ganti rugi tersebut diberikan dalam tenggang waktu 7 hari setelah tanggal transaksi. Serta sanksi pidananya ialah pelaku usaha akan dikenakan hukuman penjara 2 sampai 5 tahun dan denda mulai dari Rp 500.000.000 (lima ratus juta rupiah) sampai Rp 2.000.000.000 (dua milyar rupiah). Apabila denda tersebut masih belum bisa merubah perilaku pelaku usaha, maka akan diberikan hukuman tambahan sebagaimana diatur dalam Pasal 63 Undang-Undang Perlindungan Konsumen.
\end{abstract}

\section{Kata kunci : Pelaku Usaha Laundry, Undang-undang nomor 8 tahun 1999}

\section{PENDAHULUAN}

Di era globalisasi sekarang ini, dimana budaya bangsa asing (barat) lebih menonjolkan budaya materialistik dengan begitu mudah telah masuk ke dalam kehidupan masyarakat Indonesia perlahan mereka mulai mengetahui kegunaan dan fungsi alat elektronik. Masyarakat Indonesia pada akhirnya lebih memilih hidup dengan cara cepat, efisien, dan murah.Saat ini tampak kegiatan perekonomian yang sangat dominan dilakukan masyarakat adalah berdagang, seperti jual-beli, dan sewamenyewa barang atau jasa. Jenis usaha jasa, salah satu kegiatan bisnis yang sedang diminati masyarakat Indonesia sekarang ini.

Walaupun keinginan setiap konsumen berbeda, tetapi semua konsumen melakukan hal yang sama yaitu konsumsi barang dan jasa. Hal ini memicu berkembangnya pelaku usaha jasa yang sangat bermanfaat bagi orang-orang yang sibuk dengan kegiatannya di kantor maupun kampusnya, karena dapat meringankan atau membantu orang-orang yang tidak mempunyai waktu luang untuk mencuci dan setrika. Jasa laundry saat ini sedang diminati oleh sebagian masyarakatnya, mengikuti trend bisnis kuliner yang sedang populer. Walaupun saat ini banyak masyarakat yang menjadi pelaku usaha jasa laundry, hal ini tidak membuat pelakunya menjadi putus asa, malah menjadikan pelaku usaha menjadi lebih kreatif serta inovatif untuk dapat menarik konsumen datang ke tempatnya. 
Pelaku usaha jasa laundry adalah penyedia jasa laundry yang menawarkan layanan cuci pakaian termasuk di dalamnya jasa cuci, cuci kering, setrika, dan cuci kering setrika. Pihak-pihak dalam usaha laundry ini adalah pihak pelaku usaha jasa dan pihak masyarakat sebagai konsumen pemanfaat jasa laundry. Hubungan hukum yang terjadi di dalam kegiatan usaha laundry adalah hubungan antara pelaku usaha dengan konsumen sehingga dapat berlaku Undang-Undang Nomor 8 Tahun 1999 tentang Perlindungan Konsumen.

Pelaku usaha sebagaimana di maksud dalam Undang-Undang Nomor 8 Tahun 1999 memberikan batasan pengertian sebagai berikut : setiap orang, perorangan atau badan usaha, baik yang berbentuk badan hukum maupun bukan badan hukum yang didirikan dan berkedudukan di wilayah hukum Negara Republik Indonesia, baik sendiri maupun bersama-sama, melalui bidang perjanjian menyelenggarakan kegiatan usaha dalam berbagai bidang ekonomi.

Sedangkan pengertian jasa menurut Undang-Undang Nomor 8 Tahun 1999 adalah setiap pelayanan yang berbentuk pekerjaan atau prestasi yang disediakan bagi masyarakat untuk dimanfaatkan oleh konsumen. Selanjutnya yang diartikan konsumen adalah setiap orang pemakai barang dan/atau jasa yang tersedia dalam masyarakat, baik bagi kepentingan diri sendiri, keluarga, orang lain, maupun mahluk hidup lain dan tidak untuk diperdagangkan.

Pelaku usaha bertanggung jawab memberikan ganti kerugian atas kerusakan, pencemaran, dan kerugian konsumen akibat barang atau jasa yang dirusakkan atau dihilangkan. Beranjak dari ketentuan tersebut maka pelaku usaha jasa laundry sebagai pelaku usaha bertanggung jawab untuk memberikan ganti kerugian terhadap konsumen yang mengadakan perjanjian penyelenggaraan jasa laundry terhadapnya. Hubungan hukum antara konsumen dengan pelaku usaha jasa laundry di samping dapat didasarkan kepada UUPK (Undang-Undang Perlindungan Konsumen) juga dapat dilihat dari sudut ketentuan Kitab Undang-Undang Hukum Perdata (selanjutnya dalam penelitian ini disingkat KUH Perdata).

Tanggung jawab pelaku usaha timbul karena adanya hubungan antara produsen dengan konsumen.Pelaku usaha dapat dikenakan pertanggung jawaban apabila barang dan atau jasa yang digunakan oleh konsumen menimbulkan kerugian, produknya cacat dan berbahaya, dan bahaya terjadi tetapi tidak diketahui sebelumnya oleh konsumen.Rumusan tentang tanggung jawab pelaku usaha terdapat dalam pasal 19 Undang-Undang Nomor 8 Tahun 1999 tentang Perlindungan Konsumen.

Jasa laundry dalam penyelenggaraan kegiatan usahanya masih sering menimbulkan peristiwa-peristiwa yang merugikan konsumennya selaku pengguna jasa, misalnya seperti kasus kehilangan atau tertukarnya pakaian yang sering dialami oleh konsumen pada saat mencuci pakaiannya di jasa Laundry. Pada saat konsumen meminta ganti rugi, konsumen tidak mendapatkan pertanggungjawaban ganti rugi apapun dari pelaku usaha jasa laundry tersebut, sehingga konsumen sangat dirugikan oleh sikap pelaku usaha tersebut yang tidak bertanggungjawab atas kerugian akibat perbuatannya tersebut.

Seperti yang dijelaskan dalam UndangUndang Nomor 8 Tahun 1999 Pasal 7 tentang kewajiban pelaku usaha yang meliputi : Beritikad baik dalam melakukan kegiatan usahanya, Memberikan informasi yang benar, jelas dan jujur mengenai kondisi dan jaminan barangdan/atau jasa serta memberi penjelasan penggunaan, perbaikan dan pemeliharaan, Memperlakukan atau melayani konsumen secara benar dan jujur serta tidak diskriminatif, Menjamin mutu barang dan/atau jasa yang diproduksi dan/atau diperdagangkanberdasarkan ketentuan standar mutu barang dan/atau jasa yang berlaku, Memberi kesempatan kepada konsumen untuk menguji, dan/atau mencoba barang dan/atau jasa tertentu serta memberi jaminan dan/atau garansi atas barang yang dibuat dan/atau yang diperdagangkan, Memberi kompensasi, ganti rugi dan/atau 
penggantian atas kerugian akibat penggunaan, pemakaian dan pemanfaatan barang dan/atau jasa yang diperdagangkan, Memberi kompensasi, ganti rugi dan/atau penggantian apabila barang dan/atau jasa yang diterima atau dimanfaatkan tidak sesuai dengan perjanjian

Istilah pelaku usaha sepadan dengan pelaku bisnis dan pelaku ekonomi. Menurut Sri Redjeki Hartono pelaku-pelaku ekonomi tersebut, jika distratifikasi sesuai dengan kemampuan permodalannya, kemampuan akses pasar dalam dan luar negeri serta jumlah tenaga kerjanya. Pengertian pelaku usaha yang bermakna luas, akan memudahkan konsumen untuk menuntut ganti kerugian. Konsumen yang dirugikan akibat penggunaan produk tidak begitu kesulitan dalam menemukan kepada siapa tuntutan diajukan, karena banyak pihak yang dapat digugat, namun akan lebih baik lagi seandainya Undang-Undang Perlindungan Konsumen tersebut memberikan rincian sebagaimana dalam Directive, sehingga konsumen dapat lebih mudah lagi untuk menentukan kepada siapa ia akan mengajukan tuntutan jika ia dirugikanakibat penggunaan produk

Berdasarkan Directive tersebut yang berhak menuntut ganti kerugian adalah pihak yang menderita kerugian (karena kematian atau cedera) atau kerugian berupa kerusakan benda selain produk yang cacat itu sendiri. Pelaku usaha yang meliputi berbagai bentuk/jenis usaha sebagaimana yang dimaksud dalam Undang-Undang Perlindungan Konsumen, sebaiknya ditentukan urutan-urutan yang seharusnya digugat oleh konsumen manakala dirugikan oleh pelaku usaha.

Pelaku usaha juga mepunyai hak dan kewajibannya yang sudah diatur dalam Undang-Undang Perlindungan Konsumen. Hak pelaku usaha yang tercantum pada Pasal 6 UUPK. Pelaku usaha dan konsumen merupakan hubungan yang tidak dapat terpisahkan, melainkan seperti simbiosis mutualisme yaitu hubungan yang saling menguntungkan satu sama lain. Ini menjadikan pelaku usaha wajib memberikan kepuasan terhadap konsumen, dan konsumen merasa terpuaskan atas hasil yang diberikan oleh pelaku usaha. Hubungan antara pelaku usaha dengan konsumen dapat terjadi secara langsung maupun tidak langsung. Hubungan langsung terjadi apabila antara pelaku usaha dengan konsumen langsung terikat karena perjanjian yang mereka buat atau karena ketentuan undang-undang. Perjanjian ini diatur dalam KUHPer (Kitab Undang-Undang Hukum Perdata) Pasal 1313 artinya "Suatu perbuatan dengan mana satu orang atau lebih mengikatkan dirinya terhadap satu orang lain atau lebih". Untuk sahnya suatu perjanjian diperlukan empat syarat, sesuai Pasal 1320 Kitab Undang-Undang Hukum Perdata (KUHPerdata)

Ada empat hak dasar konsumen, yaitu : The right to safe products (Hak untuk mendapatkan produk yang aman), The right to be informed about products (Hak untuk mendapatkan informasi tentang produk yang digunakan), The right to definite choices is selecting products (Hak untuk memilih barang dengan jelas dan teliti), The right to be heard regarding consumer (Hak untuk didegar sebagai konsumen)

Berdasarkan pendapat Radburg dalam buku Hukum Perlindungan Konsumen yang ditulis oleh Ahmadi Miru menyebutkan keadilan, kemanfaatan, dan kepastian hukum sebagai "Tiga ide dasar hukum" atau "Tiga nilai dasar hukum", yang berarti dapat dipersamakan dengan asas hukum. Menurut Friedman dalam buku Hukum Perlindungan Konsumen yang ditulis oleh Ahmadi Miru menyebutkan "In terms of law, justice will be judged as how law treats people and how it distributes its benefits and cost", dan dalam hubungan ini Friedman juga mengatakan "Every function of law, general or specific, is allocative". Dan menurut Achmad Ali dalam buku Hukum Perlindungan Konsumen yang ditulis oleh Ahmadi Miru menyebutkan "Kalau dikatakan tujuan hukum sekaligus mewujudkan keadilan, kemanfaatan, dan kepastian hukum"

Setiap pelaku usaha yang ingin mendirikan suatu usaha, hal yang harus dilakukan terlebih dahulu adalah membuat 
dan mengurus surat ijin usaha. Mendirikan usaha jasa ataupunbadan usaha, pelaku usaha harus memiliki landasan hukum yang jelas sesuai dengan Undang-Undang Nomor 7 tahun 2014 tentang Perdagangan, Peraturan Daerah, dan Keputusan Bupati/Walikota.Tidak hanya landasan hukum itu saja, melainkan pelaku usaha wajib menjalankan usahanya sesuai dengan Undang-Undang Nomor 8 Tahun 1999 tentang Perlindungan Konsumen, yang mewajibkan pelaku usaha mempunyai iktikad baik kepada konsumennya.

\section{METODE PENELITIAN}

Tipe penelitian hukum yang dipergunakan adalah yuridis normatif (hukum normatif). Metode penelitian hukum normatif adalah metode penelitian hukum yang dilakukan dengan meneliti bahan pustaka atau data sekunder belaka. Oleh karena itu penelitian hukum ini difokuskan untuk mengkaji penelitian hukum tentang kaidah-kaidah atau norma-norma dalam hukum positif yang terkait dengan tanggung jawab pelaku usaha jasa laundry menurut Undang-Undang Nomor 8 Tahun 1999 tentang Perlindungan Konsumen.

Oleh karena tipe penelitian yang digunakan adalah tipe penelitian yuridis normatif, maka pendekatan masalah yang digunakan adalah pendekatan perundang-undangan (Statute Approach). Pendekatan tersebut melakukan pengkajian pengaturan perundang-undangan yang berhubungan dengan pokok permasalahan. Selain itu juga digunakan pendekatan analisis (AnaliticalApproach), pendekatan ini maksudnya menganalisa tanggung jawab pelaku usaha jasa laundry menurut Undang-Undang Nomor 8 Tahun 1999 tentang Perlindungan Konsumen.

Bahan Hukum Sekunder : Berupa semua publikasi tentang hukum yang bukan merupakan dokumen-dokumen resmi, yaitu internet, sosial media, dan majalah.

Bahan Hukum Tersier : Berupa bahan hukum yang bukan merupakan dokumen resmi, yaitu Kamus Hukum dan Kamus Bahasa Indonesia
Baik bahan primer maupun bahan sekunder dikumpulkan berdasarkan topik permasalahan yang telah dirumuskan dan diklasifikasi menurut sumber dan hirarkinya untuk dikaji secara komprehensif. Adapun bahan yang diperoleh dalam penelitian studi kepustakaan, aturan perundang-undangan, yang penulis uraikan dan dihubungkan sedemikian rupa, sehingga disajikan dalam penulisan yang lebih sistematis guna menjawab perumusan masalah yang dirumuskan. Cara pengolahan data dilakukan secara deduktif yakni menarik kesimpulan dari suatu permasalahan yang bersifat umum terhadap permasalahan kongkrit yang dihadapi.

\section{PEMBAHASAN}

Menurut Undang-Undang Nomor 8 Tahun 1999 tentang Perlindungan Konsumen Pasal 1 ayat 2, yaitu : "Konsumen adalah setiap orang pemakai barangdan/atau jasa yang tersedia dalam masyarakat, baik bagi kepentingan diri sendiri, keluarga, orang lain, maupun makhluk hidup lain dan tidak untuk diperdagangkan"

Penggunaan istilah "pemakai" dalam rumusan Pasal 1 ayat 2 UndangUndang Perlindungan Konsumen (UUPK) tersebut sesungguhnya kurang tepat, karena menimbulkan kesan barang tersebut bukan milik sendiri, walaupun sebelumnya telah terjadi transaksi jual beli. Hal lain yang juga perlu dikritisi bahwa cakupan konsumen dalam UUPK Undang-Undang Perlindungan Konsumen adalah sempit. Bahwa yang dapat dikualifikasi sebagai konsumen sesungguhnya tidak hanya terbatas pada subjek hukum yang disebut "orang", melainkan konsumen akhir yaitu "badan hukum".

Pengertian konsumen tidak hanya dalam arti yang sempit, melainkan dapat diartikan lebih luas bila dibandingkan dengan 2 (dua) rancangan undang-undang perlindungan konsumen lainnya. Pertama dalam Rancangan Undang-Undang Perlindungan Konsumen yang diajukan oleh 
Yayasan Lembaga Konsumen Indonesia, yang menentukan bahwa : "Konsumen adalah pemakai barang atau jasa yang tersedia dalam masyarakat, bagi kepentingan diri sendiri atau keluarganya atau orang lain yang tidak untuk diperdagangkan kembali."

Sedangkan yang kedua dalam naskah akhir Rancangan Akademik UndangUndang tentang Perlindungan Konsumen yang disusun oleh Fakultas Hukum Universitas Indonesia bekerja sama dengan Badan Penelitian dan Pengembangan Perdagangan Departemen Perdagangan Republik Indonesia menentukan bahwa, "Konsumen adalah setiap orang atau keluarga yang mendapatkan barang untuk dipakai dan tidak untuk diperdagangkan. ${ }^{1}$

Bahkan tidak hanya pengertian dari undang-undang saja, melainkan dari definisi atau pendapat para ahli tentang pengertian konsumen. Yang pertama pendapat menurut Homby, beliau mengatakan bahwa : "Konsumen (Consumer) adalah seseorang yang membeli barang atau menggunakan jasa; seseorang atau suatu perusahaan yang membeli barang tertentu atau menggunakan jasa tertentu; sesuatu atau seseorang yang menggunakan suatu persediaan atau sejumlah barang; setiap orang yang menggunakan barang atau jasa."

Menurut para ahli hukum, konsumen adalah sebagai pemakai terakhir dari benda dan jasa yang diserahkan kepada mereka oleh penguasa. Menurut Philip Kotler, pengertian konsumen adalah semua individu dan rumah tangga yang membeli atau memperoleh barang atau jasa untuk di konsumsi pribadi. Sedangkan menurut Aziz Nasution, konsumen pada umumnya adalah setiap orang yang mendapatkan barang atau jasa digunakan untuk tujuan tertentu. ${ }^{2}$

Setiap hari kita melakukan pemilihan atau menentukan skala prioritas karena kebutuhan tak terbatas, sedangkan sumber daya yang tersedia sangat terbatas. Konsep pemilihan ini merupakan perilaku mendasar dari konsumen.Konsep dasar perilaku konsumen menyatakan bahwa konsumen selalu berusaha untuk mencapai utilitas (utility) maksimal dalam pemakaian barang yang dikonsumsinya. Kegunaan (utility) adalah mengukur seberapa besar sebuah barang atau jasa dapat memuaskan kebutuhan seseorang.

Kegunaan atau nilai guna suatu barang dapat didasarkan dalam hal berikut ini : Nilai guna total (total utility) adalah kepuasan total yang dinikmati oleh konsumen dalam mengonsumsi sejumlah barang atau jasa tertentu secara keseluruhan. Nilai guna maksimal (marginal utility) adalah tambahan kepuasan yang dinikmati oleh konsumen dari setiap tambahan barang atau jasa yang dikonsumsinya. Nilai guna yang semakin menurun (diminishing return) atau pemenuhan secara vertical yaitu nilai guna yang diperoleh konsumen untuk setiap tambah konsumsi yang dilakukan pada mulanya meningkat, tetapi sampai pada titik tertentu akan mengalami penurunan. Nilai guna yang sama atau pemenuhan secara horizontal dikenal dengan Hukum Gossen II yang menyatakan bahwa konsumen akan melakukan konsumsi sedemikian rupa sehingga nilai guna marginal setiap barang dan jasa yang dikonsumsi akan sama, artinya unit terakhir dari masing-masing produk yang dikonsumsi memiliki nilai sama.

Menurut Herman Henrich Gossen (1818-1859) ekonomi Jerman yang dikenal dengan Hukum Gossen I (Hukum kegunaan marginal yang menurun) yang bunyinya : jika pemenuhan kebutuhan akan suatu jenis barang dilakukan secara terus-menerus, maka rasa nikmatnya mula-mula akan tinggi, namun semakin lama kenikmatan tersebut semakin menurun sampai akhir mencapai batas jenuh.

Berdasarkan kesimpulan dari para ahli yang mendefinisikan tentang konsumen bahwa ciri-ciri konsumen dibagi menjadi dua bagian yaitu : Personal Consumer (konsumen sendiri) : konsumen ini membeli atau menggunakan barang atau jasa untukpenggunaannya sendiri. Organizational Consumer (konsumen organisasi) : konsumen ini membeli atau menggunakan barang atau jasa untuk memenuhi kebutuhan dan menjalankan organisasi tersebut 
Perilaku konsumen dapat diartikan sebagai proses dan aktivitas ketika seseorang berhubungan dengan pencarian, pemilihan, pembelian, penggunaan, serta pengevaluasian produk dan jasa demi memenuhi kebutuhan dan keinginan. Perilaku konsumen merupakan hal-hal yang mendasari konsumen untuk membuat keputusan pembelian atau mempercayakan barangnya kepada pelaku usaha. Pengertian perilaku konsumen tidak hanya sebatas itu saja, melainkan menggunakan dan mengatur barang atau jasa yang mereka anggap akan memuaskan kebutuhan mereka.

Konsumen pada umumnya lebih tertarik dengan pemasaran yang menawarkan harga murah, pekerjaan bagus dan hasil memuaskan. Tidak perlu pemasaran yang berlebihan dan membohongi masyarakat dengan menyebarkan selebaran tetapi tidak sesuai dengan kenyataannya. Di karenakan pelaku usaha ingin mendapatkan keuntungan yang banyak daripada memikirkan hasil kerjanya. Apabila hasil kerja pelaku usaha bagus, maka konsumen pasti akan datang lagi dan mempromosikan usaha kita kepada orang lain tanpa kita harus mengeluarkan biaya untuk membuat selebaran atau iklan pada media cetak dan media elektronik.Serta konsumen mau mengeluarkan sumber dayanya yang terbatas seperti uang, waktu, tenaga untuk mendapatkan barang atau jasa yang di inginkan.

Syarat-syarat konsumen menurut Undang-Undang Perlindungan Konsumen (UUPK) dijelaskan sebagai berikut : Pemakai barang dan/atau jasa, baik memperolehnya melalui pembelian maupun secara cuma-cuma. Pemakaian barang dan/atau jasa untuk kepentingan diri sendiri, keluarga, orang lain dan makhluk hidup lain.Tidak untuk diperdagangkan. Tidak hanya syarat-syarat saja yang wajib diketahui oleh konsumen, tetapi hak dan kewajiban sebagai konsumen.

Berdasarkan Pasal 6 UUPK hak konsumen ialah : Hak atas kenyamanan, keamanan, dan keselamatan dalam mengonsumsi barang dan/atau jasa. Hak untuk memilih dan mendapatkan barang dan/atau jasa sesuai dengan nilai tukar dan kondisi serta jaminan yang dijanjikan. Hak atas informasi yang benar, jelas, dan jujur mengenai kondisi dan jaminan barang dan/atau jasa. Hak untuk didengar pendapat dan keluhannya atas barang dan/atau jasa yang digunakan. Hak untuk mendapatakan advokasi, perlindungan, dan upaya penyelesaian sengketa perlindungan konsumen secara patut. Hak untuk mendapat pembinaan dan pendidikan konsumen. Hak untuk diperlakukan atau dilayani secara benar dan jujur serta tidak diskriminatif. Hak untuk mendapatkan kompensasi, ganti rugi dan/atau penggantian, apabila barang dan/atau jasa yang diterima tidak sesuai dengan perjanjian atau tidak sebagaimana mestinya. Hak-hak yang diatur dalam ketentuan peraturan perundang-undangan lainnya.

Hak-hak yang disebutkan diatas, maka secara keseluruhan pada dasarnya dikenal 10 (sepuluh) macam hak konsumen, yaitu : Hak atas keamanan dan keselamatan. Hak untuk memperoleh informasi. Hak untuk memilih. Hak untuk didengar. Hak untuk memperoleh kebutuhan hidup. Hak untuk memperoleh ganti rugi. Hak untuk memperoleh pendidikan konsumen. Hak untuk memperoleh lingkungan hidup yang bersih dan sehat. Hak untuk mendapatkan barang sesuai dengan nilai tukar yang diberikannya. Hak untuk mendapatkan upaya penyelesaian hukum yang patut.

Hak-hak tersebut diuraikan sebagai berikut : Hak atas keamanan dan keselamatan Hak atas keamanan dan keselamatan ini dimaksudkan untuk menjamin keamanan dan keselamatan konsumen dalam penggunaan barang atau jasa yang diperolehnya, sehingga konsumen dapat terhindar dari kerugian apabila mengonsumsi suatu produk. Hak untuk memperoleh informasi Hak atas informasi ini sangat penting, karena tidak memadainya informasi yang disampaikan kepada konsumen dan dapat juga merupakan salah satu bentuk cacat produk, yaitu yang dikenal dengan cacat instruksi atau cacat karena informasi yang tidak memadai. Hak untuk memilih. Hak untuk memilih dimaksudkan 
untuk memberikan kebebasan kepada konsumen untuk memilih produk-produk tertentu sesuai dengan kebutuhannya, tanpa ada tekanan dari pihak luar. Hak untuk didengar. Hak untuk didengar merupakan hak dari konsumen agar tidak dirugikan lebih lanjut, atau hak untuk menghindarkan diri dari kerugian. Hak untuk memperoleh kebutuhan hidup

Hak merupakan hak yang sangat mendasar, karena menyangkut hak untuk hidup. Terutama yang berupa hak atas pangan, sandang, papan, serta hak-hak lainnya yang berupa hak untuk memperoleh pendidikan, kesehatan, dan lain-lain.Hak untuk memperoleh ganti kerugian. Hak atas ganti kerugian dimaksudkan untuk memulihkan keadaan yang telah menjadi rusak akibat adanya penggunaan barang atau jasa yang tidak memenuhi harapan konsumen. Hak untuk memperoleh pendidikan konsumen. Hak untuk memperoleh pendidikan konsumen dimaksudkan agar konsumen memperoleh pengetahuan maupun keterampilan yang diperlukan agar dapat terhindar dari kerugian dapat terhindar dari kerugian akibat penggunaan produk, karena dengan pendidikan konsumen tersebut, konsumen akan dapat menjadi lebih kritis dan teliti dalam memilih suatu produk yang dibutuhkan.

Hak memperoleh lingkungan hidup yang bersih dan sehat. Hak atas lingkungan yang bersih dan sehat ini sangat penting bagi setiap konsumen dan lingkungan. Hak untuk mendapatkan barang sesuai dengan nilai tukar yang diberikannya Hak yang dimaksudkan untuk melindungi konsumen dari kerugian akibat permainan harga secara tidak wajar. Karena dalam keadaan tertentu konsumen dapat saja membayar harga suatu barang yang jauh lebih tinggi daripada kegunaan atau kualitas dan kuantitas barang atau jasa yang diperolehnya. Hak untuk mendapatkan upaya penyelesaian hukum yang patut Hak yang dimaksudkan untuk memulihkan keadaan konsumen yang telah dirugikan akibat penggunaan produk, dengan melalui jalur hukum.
Adapun kewajiban konsumen yang dijelaskan dalam Pasal 5 Undang-Undang Perlindungan Konsumen (UUPK) yaitu sebagai berikut : Membaca atau mengikuti petunjuk informasi dan prosedur pemakaian atau pemanfaatan barang dan/atau jasa demi keamanan dan keselamatan. Beriktikad baik dalam melakukan transaksi pembelian barang dan/atau jasa. Membayar sesuai dengan nilai tukar yang disepakati. Mengikuti upaya penyelesaian hukum sengketa perlindungan konsumen secara patut.

Prinsip atau teori tentang kedudukan konsumen dapat diartikan menjadi 4 (empat) bagian yaitu : Let the Bayer beware Artinya letakkanlah konsumen tersebut pada posisi yang seimbang, maksudnya kedudukan antara konsumen dan pelaku usaha berada posisi yang seimbang maka tidaklah perlu konsumen mendapatkan perlindungan yang berlebihan.Hambatannya : -Konsumen tidak mendapatkan akses informasi terhadap barang dan jasa -Pengetahuan yang terbatas pada konsumen.

The Due care theory Artinya bahwa dalam kedudukan konsumen dan pelaku usaha yang harus berhati-hati adalah pengusaha. Dalam menawarkan barang dan jasanya siapapun tidak dapat dipermasalahkan apabila konsumen dirugikan. Konsumen harus membuktikan kecerobohan pelaku usaha (Pasal 1865 BW). The Privity of Contract Artinya konsumen yang kan mendapat ganti rugi dari pelaku usaha adalah konsumen yang berikan kontraktual dengan pelaku usaha. Contoh : Konsumen yang mendapatkan barang dengan cara adanya perjanjian. Orang yang memiliki barang dengan tanpa perjanjian maka konsumen tidak dapat menuntut ganti rugi kedudukan pelaku usaha setara dengan konsumen. Kemauan pelaku usaha harus diikuti oleh konsumen. Misal perjanjian standart yang diterapkan oleh pelaku usaha maka konsumen tidak dapat melakukan tawar menawar karena yang dijanjikan hanya yang besar saja sedangkan masalah kecil dikesampingkan. 
Kontrak bukalah syarat untuk mendapatkan perlindungan konsumen Artinya konsumen itu tetap dilindungi walau tanpa dalam hubungan perjanjian itu ada syarat atau kontrak terlebih dahulu. Munculnya kontrak ini karena adany transaksi yang bermacam-macam dalam dunia perekonomian kecuali untuk jasa secara ringkas transaksi konsumen sangat luas sekali. Kewajiban seperti yang diatur dalam UUPK dianggap tepat, sebab kewajiban ini adalah untuk mengimbangi hak konsumen untuk mendapatkan upaya penyelesaian sengketa perlindungan konsumen secara patut. Hak ini akan lebih mudah diperoleh jika konsumen mengikuti upaya penyelesaian sengketa secara patut. Hanya saja kewajiban konsumen, tidak cukup untuk maksud tersebut jika tidak diikuti oleh kewajiban yang sama dari pihak pelaku usaha. Seperti diketahui bahwa Undang-Undang Perlindungan Konsumen menetapkan tujuan perlindungan konsumen antara lain adalah mengangkat harkat kehidupan konsumen, maka untuk itu berbagai hal yang membawa akibat negatif dari pemakaian barang dan/atau jasa harus dihindarkan dari aktivitas perdagangan pelaku usaha.

Dalam menjalankan sebuah usaha, pelaku usaha perlu memperhatikan aturanaturan yang telah diatur dalam UUPK yang telah disahkan oleh Dewan Perwakilan Rakyat Republik Indonesia (DPR RI) pada tanggal 20 April 1999. Pada salah satu aturan yang harus diingat dan dipatuhi oleh semua pelaku usaha, ialah tentang perbuatan yang dilarang bagi pelaku usaha. Aturan ini dibuat untuk melindungi hak konsumen, agar pelaku usaha tidak seenaknya sendiri dalam menjalankan usahanya.

Perbuatan yang dilarang bagi pelaku usaha diatur dalam Pasal 16 yang berbunyi :"Pelaku usaha dalam menawarkan barang dan/atau jasa melalui pesanan dilarang untuk :Tidak menepati pesanan dan/atau kesepakatan waktu penyelesaian sesuai dengan yang dijanjikan. Tidak menepati janji atas suatu pelayanan dan/atau prestasi.
Larangan dalam Pasal 16 UUPK menjadikan perbuatan tidak menepati pesanan dan/atau tidak menepati kesepakatan waktu penyelesaian sesuai dengan yang dijanjikan, termasuk tidak menepati janji atas suatu pelayanan dan/atau prestasi, tidak saja dapat dituntut berdasarkan wanprestasi tetapi lebih dari itu dapat dituntut atas dasar perbuatan melawan hukum.

Pada Pasal 17 UUPK (Undang-Undang Perlindungan Konsumen) berbunyi : Pelaku usaha periklanan dilarang memproduksi iklan yang : Mengelabui konsumen mengenai kualitas, kuantitas, bahan, kegunaan dan harga barang dan/atau tarif jasa, serta ketetapan waktu penerimaan barang dan/atau jasa. Mengelabui jaminan/garansi terhadap barang dan/atau jasa. Memuat informasi yang keliru, salah, atau tidak tepat mengenai barang dan/atau jasa; pernyataan yang salah. Tidak memuat informasi mengenai resiko pemakaian barang dan/atau jasa. Mengeksploitasi kejadian dan/atau sesorang tanpa seizin yang berwenang atau persetujuan yang bersangkutan. Melanggar etika dan/atau ketentuan peraturan perundang-undangan mengenai periklanan. Untuk melindungi konsumen agar tidak dirugikan dari segi mutu barang, maka dapat ditempuh dengan berbagai cara, antara lain :

Standar Mutu Berkenaan dengan pengawasan kualitas/mutu barang dalam World Trade Organization (WTO) telah dicapai persetujuan tentang hambatan teknis dalam perdagangan, untuk menjamin aturan teknis atau standar teknis demi keselamatan umum dan perlindungan konsumen. HaKI (Hak atas Kekayaan Intelektual)/Merek Perlindungan konsumen di bidang mutu barang, juga dapat terjadi dengan pemenuhan ketentuan tentang Hak atas Kekayaan Intelektual (HaKI). Dengan adanya Persetujuan Pembentukan Organisasi Perdagangan Dunia, yaitu memiliki arti persetujuan tentang aspek-aspek dagang dari Hak atas Kekayaan Intelektual (HaKI) atau Trade Related Aspects of Intellectual Property Rights (TRIPs) maka hal ini adalah satu langkah maju dalam bidang 
perlindungan HaKI (Hak atas Kekayaan Intelektual) karena adanya persetujuan setiap anggota diwajibkan untuk mengikuti ketentuan-ketentuan yang tercantum di dalamnya.

Daluwarsa Di samping keamanan produk pada saat proses produksi suatu produk juga kualitasnya dapat menurun karena perjalanan waktu. Berkaitan dengan pencantuman tanggal daluwarsa pada label suatu produk, perlu mendapat perhatian agar tidak terjadi salah pengertian, karena tanggal daluwarsa tersebut bukan merupakan batas mutlak suatu produk dapat digunakan. Tanggal daluwarsa hanya merupakan perkiraan produsen berdasarkan hasil studi atau pengamatannya, sehingga barang yang sudah melewati masa daluwarsanya masih dapat digunakan sepanjang dalam kenyataannya produk tersebut masih aman untuk digunakan. Sebaliknya, suatu produk dapat menjadi rusak atau berbahaya untuk digunakan sebelum tanggal daluwarsa yang tercantum pada label produk tersebut pudar. Pengawasan Produk Impor Selain berbagai ketentuan yang bermaksud mencegah terjadinya kerugian bagi masyarakat, pemerintah juga melkukan tindakan segera yang bermaksud mengatasi masalah yang tealah terjadi atau mencegah terjadinya masalah kesehatan di Indonesia sebagai akibat masuknya barang-barang berbahaya di Indonesia. Ketentuan perundangundangan di bidang perdagangan tidak mengabaikan, bahkan sangat memperhatikan kepentingan perlindungan konsumen

Setiap pelaku usaha pasti akan mempunyai masalah, hanya saja cara mengatasi masalah tersebut tiap pelaku usaha pasti berbeda-beda. Agar pelaku usaha dapat mngetahui dan memahami masalah dan saksi yang mereka hadapi, apabila mereka melanggar peraturan yang sudah ditetapkan sesuai UUPK. Yang pertama berdasarkan Pasal 60 UUPK sanksi administratif yaitu : Badan Penyelesaian Sengketa Konsumen berwenang menjatuhkan sanksi administratif terhadap pelaku usaha yang melanggar Pasal 19 ayat 2, dan ayat 3, Pasal 20, Pasal 25, dan Pasal 26. Sanksi administratif berupa penetapan ganti rugi paling banyak Rp 200.000.000,00 (dua ratus juta rupiah). Tata cara penetapan sanksi administratif sebagaimana dimaksud pada ayat 1 diatur lebih lanjut dalam peraturan perundang-undangan.

Pengaturan kewenangan Badan Penyelesaian Sengketa Konsumen (BPSK) untuk menjatuhkan sanksi administratif sesungguhnya bermasalah. Selama ini pemahamn terhadap sanksi administratif tertuju pada sanksi yang berupa pencabutan izin usaha atau sejenisnya. Melalui pemahaman praktik di lingkungan peradilan umum dalam hal menemukan adanya pelanggaran yang memerlukan dijatuhkannya sanksi administratif kepada pelaku usaha, maka dalam putusannya memerintahkan instansi penerbit izin usaha untuk melakukan pecabutan izin usaha pihak pelaku yang bersangkutan.

Apabila ada dokumen yang bermasalah seperti sertifikat tanah, hakim Pengadilan Negeri mengeluarkan putusan yang berisi perintah kepada Badan Pertanahan untuk mencabut atau membatalkan sertifikat yang bersangkutan. Jadi dalam hal ini pihak pengadilan tidak punya kewenangan menjatuhkan sanksi administratif, tetapi memiliki kewenangan untuk memerintahkan instansi yang berwenang untuk melakukan pencabutan izin usaha atau pembatalan dokumen yang telah diterbitkan oleh instansi yang bersangkutan.

Seandainya ada dokumen yang bermasalah seperti sertifikat tanah, hakim Pengadilan Negeri mengeluarkan putusan yang berisi perintah kepada Badan Pertanahan, untuk mencabut atau membatalkan sertifikat yang bersangkutan. Dalam hal ini pihak pengadilan tidak punya kewenangan menjatuhkan sanksi administratif, tetapi memiliki kewenangan untuk memerintahkan instansi yang berwenang untuk melakukan pencabutan izin usaha atau pembatalan dokumen yang telah diterbitkan oleh instansi yang bersangkutan.

Pemahaman masyarakat dalam praktik pengadilan ternyata dijungkir balikkan oleh ketentuan Pasal 60 UUPK. 
Disebabkan karena di satu sisi dinyatakan BPSK berwenang menjatuhkan sanksi administratif, sementara di sisi lain ternyata yang dimaksudkan adalah sanksi perdata. Dari sis penggunaan istilah sanksi administratif, BPSK tidak memiliki kewenangan oleh karenanya ia bukan merupakan instansi penerbit izin, sehingga hak atau kewenangan menjatuhkan sanksi administratif oleh BPSK secara hukum tidak berdasar. Tetapi dari sisi substansi pada dasarnya adalah sanksi perdata, sehingga mengenai hal ini dapat dipastikan bahwa tidak ada pihak yang menyangsikan kewenangan tersebut.

Ganti rugi dengan dijatuhi sanksi yang jumlahnya maksimum $\mathrm{Rp}$ 200.000.000,00 (dua ratus juta rupiah) merupakan bentuk pertanggung gugatan terbatas, sehingga secara keseluruhan dapat dikatakan bahwa ganti rugi yang dianut dalam UUPK menganut prinsip ganti rugi subjektif terbatas. Adanya pembatasan ganti rugi atau subjektif terbatas ditujukan untuk kondisi Indonesia sebagai negara yang industrinya masih dalam perkembangan dinilai tepat. Karena memberikan perlindungan kepada konsumen juga pelaku usaha masih terlindungi atau dapat terhindar dari kerugian yang mengakibatkan kebangkrutan akibat pembayaran ganti rugi yang tanpa batas.

Sanksi pidana dapat dikenakan apabila pelaku usaha melanggar peraturan, sesuai dengan Pasal 62 UUPK yang meliputi : Pelaku usaha yang melanggar ketentuan sebagaimana dimaksud dalam Pasal 8, Pasal 9, Pasal 10, Pasal 13 ayat 2, Pasal 15, Pasal 17 ayat 1 huruf a, huruf $b$, huruf $c$, huruf e, ayat 2 dan pasal 18 dipidana dengan pidana penjara paling lama 5 (lima) tahun atau pidana denda paling banyak $\mathrm{Rp}$ 2000.000.000,00 (dua milyar rupiah). Pelaku usaha yang melanggar ketentuan sebagaimana dimaksud dalam Pasal 11, Pasal 12, Pasal 13 ayat 1, Pasal 14, Pasal 16, dan Pasal 17 ayat 1 huruf $\mathrm{d}$ dan huruf $\mathrm{f}$ dipidana dengan pidana paling lama 2 (dua) tahun atau pidana denda paling banyak $\mathrm{Rp}$ $500.000 .000,00$ (lima ratus juta rupiah).
Terhadap pelanggaran yang mengakibatkan luka berat, sakit berat, cacat

Sanksi pidana yang berupa denda sebagaimana dikemukakan di atas, dalam KUHP termasuk dalam jenis hukuman pokok, sebagaimana dapat dilihat dalam Pasal 10 yang menentukan bahwa :Hukuman-hukuman pokok : Hukuman mati. Hukuman penjara. Hukuman kurungan. Hukuman dendaHukuman. -hukuman tambahan: Pencabutan beberapa hak tertentu. Perambasan barang tertentu. Pengumuman keputusan hakim

Adanya sanksi pidana denda yang dipandang sekedar ongkos operasional produksi atau pemasaran, akibatnya pelaku usaha sebagai subjek hukum pidana tidak menjadi jera atau sanksi pidana denda yang dimaksud tidak mengubah perilaku pelaku usaha. Jika hal ini terjadi berarti sanksi pidana denda saja, masih belum cukup teristimewa sanksi denda yang jumlahnya kecil sehingga harus ada pertimbangan terhadap kemungkinannya memberikan sanksi tambahan sebagaimana diatur dalam Pasal 63 UUPK yaitu :"Terhadap sanksi pidana sebagaimana dimaksud dalam Pasal 62 dapat dijatuhkan hukuman tambahan, berupa : Perampasan barang tertentu. Pengumuman keputusan hakim. Pembayaran ganti rugi. Perintah penghentian kegiatan tertentu yang menyebabkan timbulnya kerugian konsumen. Kewajiban penarikan barang dari peredaran. Pencabutan izin usaha. ${ }^{3}$

Sedangkan dalam sanksi perdata pelaku usaha wajib membayar ganti rugi, dalam bentuk :

Pengembalian uang Penggantian barang Perawatan kesehatan Pemberian santunan Ganti rugi diberikan dalam tenggang waktu 7 hari setelah tanggal transaksi.

Pelaku usaha dalam menjalankan usahanya pasti akan menemui kendala atau hambatan yang dapat membuat pelaku usaha harus bertanggung jawab atas kelalaian ataupun kerusakan barang dan/atau jasa yang dilakukannya. Bahwasannya dalam Undang-Undang Perlindungan Konsumen 
Nomor 8 Tahun 1999 terdapat 3 (tiga) pasal yang menggambarkan sistem tanggung jawab pelaku usaha dalam perlindungan konsumen di Indonesia.Dalam Pasal 19 UUPK, dijelaskan bahwa : Pelaku usaha bertanggung jawab memberikan ganti rugi atas kerusakan, pencemaran, dan/atau kerugian konsumen akibat mengonsumsi barang dan/atau jasa yang dihasilkan atau diperdagangkan.

Ganti rugi sebagaimana yang dimaksud ayat 1 dapat berupa pengembalian uang atau penggantian barang dan/atau jasa yang sejenis atau setara nilainya, atau perawatan kesehatan dan/atau pemberian santunan yang sesuai dengan ketentuan peraturan perundang-undangan. Pemberian ganti rugi dilaksanakan dalam tenggang waktu 7 (tujuh) hari setelah tanggal transaksi. Pemberian ganti rugi sebagaimana dimaksud pada ayat 1 dan 2 tidak menghapuskan kemungkinan adanya tuntutan pidana berdasarkan pembuktian lebih lanjut mengenai adanaya unsur kesalahan. Ketentuan sebagaimana dimaksud pada ayat 1 dan 2 tidak berlaku apabila pelaku usaha dapat membuktikan bahwa kesalahan tersebut merupakan kesalahan konsumen

Berdasarkan hal ini, adanya produk barang dan/atau jasa yang cacat bukan merupakan satu-satunya dasar pertanggung jawaban pelaku usaha. Bahwa tanggung jawab pelaku usaha meliuti segala kerugian yang dialami konsumen. Lingkup tanggung jawab pembayaran ganti rugi secara umum, tuntutan ganti rugi atas kerugian yang dialami oleh konsumen sebagai akibat penggunaan produk, baik yang berupa kerugian materi, fisik, maupun jiwa, dapat didasarkan pada beberapa ketentuan yang telah disebutkan.

Secara garis besarnya, hanya ada dua kategori yaitu tuntutan ganti kerugian berdasarkan wanprestasi dan tuntutan ganti kerugian yang berdasarkan perbuatan melanggar hukum. Maka dari itu tuntutan ganti kerugian dibahas secara khusussebagai berikut ini : Tuntutan Berdasarkan Wanprestasi Dalam penerapan lingkungan hukum privat, terdapat perbedaan esensial antara tuntutan ganti kerugian yang didasarkan pada wanprestasi dengan tuntutan ganti kerugian yang didasarkan pada perbuatan melanggar hukum. Apabila tuntutan ganti rugi didasarkan pada wanprestasi, maka terlebih dahulu tergugat dengan penggugat terikat suatu perjanjian. Ganti rugi yang diperoleh karena adanya wanprestasi akibat tidak dipenuhinya kewajiban utama atau kewajiban tambahan yang berupa kewajiban atas prestasi utama atau kewajiban jaminan/garansi dalam perjanjian. Dalam tanggung gugat berdasarkan adanya wanprestasi, kewajiban untuk membayar ganti kerugian tidak lain daripada akibat penerapan klausula dalam perjanjian, yang merupakan ketentuan hukum yang oleh kedua pihak secara sukarela tunduk berdasarkan perjanjian.

Tuntutan Berdasarkan

Perbuatan Melanggar Hukum Berbeda dengan tuntutan ganti kerugian yang didasarkan pada perikatan yang lahir dari perjanjian, tuntutan ganti rugi yang didasarkan pada perbuatan melanggar hukum tidak perlu didahului dengan perjanjian antara pelaku usaha dengan konsumen. Untuk dapat menuntut ganti rugi, maka kerugian tersebut harus merupakan akibat dari perbuatan melanggar hukum. Hal ini berarti bahwa untuk dapat menuntut ganti rugi harus dipenuhi unsur-unsur sebagai berikut : Ada perbuatan melanggar hukum. Ada kerugian. Ada hubungan kausalitas antara perbuatan melanggar hukum dan kerugian. Ada kesalahan. Dengan unsurunsur di atas, maka dapat diuraikan sebagaimana dimaksudkan :Perbuatan Melanggar Hukum. Berbeda dengan pengertian perbuatan melanggar hukum sebelum tahun 1919 yang diidentikkan dengan perbuatan melanggar undangundang, maka setelah tahun 1919 perbuatan melanggar hukum tidak lagi hanya sekedar melanggar undang-undang, melainkan perbuatan melanggar hukum tersebut dapat berupa : Melanggar hak orang lain. Bertentangan dengan kewajiban hukum si pembuat. Berlawanan dengan kesusilaan baik. Berlawanan dengan sikap hati-hati yang seharusnya diindahkan dalam 
pergaulan masyarakat terhadap diri atau benda orang lain.

Bertentangan dengan kewajiban hukum si pembuat, sebagai bentuk kedua dari perbuatan melanggar hukum. Kewajiban hukum yang dimaksud adalah kewajiban menurut undang-undang, baik yang termasuk hukum publik maupun hukum privat. Berdasarkan yurisprudensi melanggar kewajiban undang-undang tidak begitu saja merupakan perbuatan melanggar hukum, karena memiliki persyaratan tertentu yaitu : Dengan pelanggaran ini, kepentingan penggugat dilanggar atau diancam.

Kepentingan itu dilindungi oleh kewajiban yang dilanggar. Kepentingan itu termasuk yang dilindungi berdasarkan Pasal 1365 BW. Pelanggaran tersebut bersifat tidak pantas terhadap si penggugat mengingat sikap dan perbuatannya sendiri. Tidak ada alasan pembenar.

Apabila syarat-syarat tersebut dipenuhi, maka pelanggaran atas kewajiban hukum merupakan perbuatan melanggar hukum. Yang menjadi prinsip pokok tanggung gugat adalah bahwa pihak tergugat berkewajiban terhadap pihak penggugat, yaitu kewajiban untuk bertindak hati-hati dan sedangkan pihak penggugat harus membuktikan bahwa ia telah menderita kerugian akibat pelanggaran kewajiban.

Kerugian Dalam menentukan besarnya gantikerugian yang harus dibayar, pada dasarnya harus berpegang pada asas bahwa ganti kerugian yang harus dibayar sedapat mungkin membuat pihak yang rugi dikembalikan pada kedudukan semula seandainya tidak terjadi kerugian atau dengan kata lain ganti kerugian menempatkan sejauh mungkin orang yang dirugikan dalam kedudukan yang seharusnya andaikata perjanjian dilaksanakan secara baik atau tidak terjadi perbuatan melanggar hukum. Walaupun demikian, menghitung besarnya kerugian sering tidak mudah sehingga sering ditetapkan berdasarakan keadilan. Ganti kerugian dalam UUPK, hanya meliputi pengembalian uang tau penggantian barang dan/atau jasa yang sejenis atau setara nilainya, atau perawatan kesehatan dan/atau pemberian santunan yang sesuai dengan peraturan perundangundangan yang berlaku.

Hubungan Sebab Akibat. Pada tahun 1962, Koster menyarankan untuk menghapus adequat dan menerima toerrekening naar redelijkheid, serta memasukkan toerrekening naar redelijkheid (dipertanggungkan secara layak) ini dalam B.W. baru. Faktor penting yang disebut oleh Koster dalam sarannya tersebut adalah : Sifat dari kejadian yang menjadi dasar pertanggung gugatan. Sifat kerugian.

Besar kecilnya kerugian yang diperkirakan akan terjadi. Beban tidak seimbang yang dapat timbul bagi pihak tergugat dari kewajibannya untuk membayar ganti rugi, serta memperhatikan keadaan keuangan pihak yang dirugiakn. Kesalahan. Berdasarkan Pasal 1365 B.W., salah satu syarat untuk membebani tergugat dengan tanggug gugat berdasarkan perbuatan melanggar hukum adalah adanya kesalahan. Kesalahan ini memilik 3 (tiga) unsur yaitu : Perbuatan yang dilakukan dapat disesalkan. Perbuatan tersebut dapat diduga akibatnya : Dalam arti objektif ; sebagai manusia normal dapat menduga. Dalam arti subjektif ; sebagai seorang ahli dapat menduga akibatnya.

Dapat dipertanggung jawabkan ; debitur dalam keadaan cakap. Pada Negara Amerika Serikat untuk pertama kalinya konsumen hanya dapat diberikan perlindungan hukum jika terdapat hubungan kontrak dengan pelaku usaha, karena berlaku asas "no privity-no liability", yang berarti bahwa pihak ketiga tidak memiliki dasar untuk menggugat apabila mengalami kerugian akibat penggunaan produk cacat, karena dasar gugatan hanya wanprestasi, dan tidak memungkinkan didasarkan pada alasan perbuatan melanggar hukum. Dan asas ini juga pernah pertama kali ditinggalkan atau runtuh pada tahun 1852, intinya adalah bahwa pelaku usaha bertanggung gugat juga terhadap pihak ketiga atas barang yang sangat berbahaya. Tidak diterapkannya asas tersebut pada mulanya hanya dimaksudkan untuk produk yang tergolong berbahaya, karena jika kurang hati-hati dalam 
memberikan etiket maka akan membahayakan hajat hidup manusia.

Dengan ditinggalkannya asas tersebut membawa akibat bahwa siapapun yang menjadi korban produk cacat berhak penuh mengajukan gugatan, termasuk bystander. Syarat pemakaian jaminan adalah bahwa pada saat perjanjian ditanda tangani, jelas bagi pelaku usaha bahwa barang tersebut di maksudkan untuk tujuan tertentu dan konsumen percaya pada pengetahuan teknik dan keahlian pelaku untuk membuat barang yang dipercyakan menjadi indah dan bersih dengan tujuan yang diinginkan untuk digunakan

Berdasarkan sistem tanggung jawab produk Pasal 23 Undang-Undang Perlindungan Konsumen, yang berbunyi : "Pelaku usaha yang menolak dan/atau tidak memberi tanggapan dan/atau tidak memenuhi ganti rugi atas tuntutan konsumen sebagaimana dimaksud dalam Pasal 19 ayat 1 , ayat 2, ayat 3, dan ayat 4, dapat digugat melalui Badan Penyelesaian Sengketa Konsumen atau mengajukan ke badan peradilan di tempat kedudukan konsumen."

Ketentuan Pasal 23 UUPK merupakan suatu hal baru dalam dunia peradilan di Indonesia, dan dapat dikatakan sebagai langkah maju dilakukan oleh Pemerintah Indonesia dalam memberdayakan konsumen menuntut haknya atas ganti rugi terhadap pihak pelaku usaha. Gugatan sengketa balik dapat dilakukan apabila konsumen mencemarkan nama baik pelaku usaha tanpa adanya bukti yang konkret dan jelas.

Terdapat dalam Pasal 28 UndangUndang Perlindungan Konsumen dijelaskan bahwa: "Pembuktian terhadap ada tidaknya unsur "kesalahan" dalam gugatan ganti rugi sebagaimana dimaksud pasal 19, pasal 22, dan pasal 23 merupakan beban dan tanggung jawab pelaku usaha."

Hal ini meberikan konsekuensi hukum bahwa pelaku usaha yang dapat membuktikan kerugian bukan merupakan kesalahannya terbebas dari tanggung jawab ganti kerugian. Ketetntuan tentang beban pembuktian dalam hukum acara hukum perdata merupakan suatu bagian yang sangat penting dan menentukan dapat tidaknya suatu tuntutan perdata (gugatan) dikabulkan, karena pembebanan pembuktian yang salah oleh hakim dapat mengakibatkan seseorang yang seharusnya memenangkan perkara menjadi pihak yang kalah hanya karena tidak mampu membuktikan sesuatu yang sebenarnya menjadi haknya.

Apabila asas umum beban pembuktian diterapkan dalam kasus-kasus kerugian konsumen akibat penggunaan barang, maka berarti bahwa baik pelaku usaha maupun konsumen dibebani pembuktian. Konsumen harus membuktikan : Adanya perbuatan melanggar hukum. Adanya kesalahan pelaku usaha. Adanya kerugian konsumen. Adanya hubungan kausal antara perbuatan melanggar hukum dari pelaku usaha dengan kerugian konsumen. Konsumen hanya dibebaskan dari pembuktian yang demikian apabila kerugian yang dialami oleh konsumen tersebut diakibatkan oleh wanprestasi produsen. (Pasal 1244 B.W.)

Pembuktian tanggung gugat pelaku usaha karena adanya perbuatan melanggar hukum yang berlaku secara umum dalam hukum pembuktian, yaitu membebankan kepada penggugat untuk membuktikan adanya kesalahan tergugat yang menyebabkan kerugiannya. Namun berhasil tidaknya pelaku usaha membuktikan bersalah tidaknya atas kerugian konsumen, sangat menentukan bebas tidaknya pelaku usaha dari tanggung gugat untuk membayar ganti rugi terhadap konsumen.

Di negara maju, pembuktian pada umumnya dibebankan kepada pelaku usaha dan hanya hal-hal tertentu dibebaskan dari tanggung gugat. Pembalikkan beban pembuktian merupakan salah satu bentuk pemberdayaan konsumen, terutama jika telah terjadi kerugian akibat penggunaan barang, karena sekalipun tanggung gugat yang diterapkan adalah tanggung gugat berdasarkan kesalahan, namun konsumen tidak lagi dibebani untuk membuktikan kesalahan pelaku usaha melainkan pelaku usaha yang harus membuktikan ketidakbersalahannya. 
Apabila pelaku usaha tidak mampu membuktikan ketidak bersalahannya, maka dengan sendirinya dianggap bersalah, sehinnga bertanggung gugat untuk membayar ganti rugi yang ditimbulkan. Pembalikan beban pembuktian merupakan ketentuan beban bersifat khusus sebagai penyimpangan atas ketentuan umum bahwa penggugat harus membuktikan kesalahan tergugat dalam kasus perbuatan melanggar hukum, yang telah diatur dalam UUPK. Menurut Hofmann, perhitungan tanggung gugat dari masing-masing kesalahan dari si pelaku dan pihak yang dirugikan dalam pihak yang dirugikan turut bersalah dalam menimbulkan kerugian tiga pokok :

Dihapuskan sama sekali tanggung gugat pada tiap kesalahan sendiri dari pihak yang dirugikan. Tanggung gugat dihapuskan hanya kalau kesalahan sendiri lebih besar daripada kesalahan pihak lawan, kalau tidak maka tanggung gugat sepenuhnya pada pihak lawan. Pengurangan tanggung seperti yang didasarkan pad perbandingan kesalahan Bukan hanya pelaku usaha saja yang harus bertanggung jawab, melainkan pemerintah juga. Seperti yang dijelaskan dalam Pasal 29, yaitu : Pemerintah bertanggung jawab atas pembinaan penyelenggaraan perlindungan konsumen yang menjamin diperolehnya hak konsumen dan pelaku usaha serta dilaksanakannya kewajiban konsumen dan pelaku usaha. Pembinaan oleh pemerintah atas penyelenggaraan perlindungan konsumen sebagaimana dimaksud pada ayat 1 dilaksanakan oleh menteri dan/atau mnteri teknis terkait. Menteri sebagaimana di maksud pada ayat 2 melakukan koordinasi atas penyelenggaraan perlindungan konsumen. Pembinaan penyelenggaraan perlindungan konsumen sebagaimana dimaksud pada ayat 2 meliputi upaya untuk : Terciptanya iklim usaha dan tumbuhnya hubungan yang sehat antara pelaku usaha dan konsumen. Berkembangnya lembaga perlindungan konsumen swadaya masyarakat. Meningkatnya kualitas sumber daya serta meningkatnya kegiatan penelitian dan pengembangan di bidang perlindungan dengan konsumen. Ketentuan lebih lanjut mengenai pembinaan penyelenggaraan perlindungan konsumen diatur dengan Peraturan Pemerintah.

Dengan demikian, kewajiban untuk berhati-hati bukan hanya dibebankan kepada pelaku usaha melainkan juga konsumen. Pelaku usaha juga harus teliti dan melihat ulang barang yang akan di cuci, agar tidak terjadi suatu masalah. Agar semua pihak seprti pelaku usaha dan konsumen tidak ada yang dirugikan satu sama lainnya.

\section{KESIMPULAN DAN SARAN SIMPULAN}

Di negara maju, pembuktian pada umumnya dibebankan kepada pelaku usaha dan hanya hal-hal tertentu dibebaskan dari tanggung gugat. Pembalikkan beban pembuktian merupakan salah satu bentuk pemberdayaan konsumen, terutama jika telah terjadi kerugian akibat penggunaan barang, karena sekalipun tanggung gugat yang diterapkan adalah tanggung gugat berdasarkan kesalahan, namun konsumen tidak lagi dibebani untuk membuktikan kesalahan pelaku usaha melainkan pelaku usaha yang harus membuktikan ketidakbersalahannya.

Apabila pelaku usaha tidak mampu membuktikan ketidak bersalahannya, maka dengan sendirinya dianggap bersalah, sehinnga bertanggung gugat untuk membayar ganti rugi yang ditimbulkan. Pembalikan beban pembuktian merupakan ketentuan beban bersifat khusus sebagai penyimpangan atas ketentuan umum bahwa penggugat harus membuktikan kesalahan tergugat dalam kasus perbuatan melanggar hukum, yang telah diatur dalam UUPK.

Pelaku usaha sebelum menjalankan usahanya wajib mematuhi peraturan yang sudah ditetapkan berdasarkan UndangUndang Nomor 8 Tahun 1999 tentang Perlindungan Konsumen. Dalam undangundang tersebut diatur tentang hak dan kewajiban pelaku usaha dan konsumen, perbuatan yang dilarang bagi pelaku usaha, tanggung jawab pelaku usaha, dan sanksi yang harus diterima oleh pelaku usaha apabila melakukan pelanggaran. 
Tanggung jawab pelaku usaha diatur dalam pasal 19 Undang-Undang Perlindungan Konsumen. Apabila pelaku usaha dalam menjalankan usahanya menyalahi aturan yang sudah ditetapkan, maka pelaku usaha wajib kenai sanksi. Dan sanksi yang diberikan ada 3, yaitu :

$>$ Sanksi Administrasi : Bila terjadi pelanggaran, pelaku usaha wajib membayar denda yang sudah ditetapkan dan izin usaha akan dicabut oleh BPSK.

> Sanksi Perdata : Pelaku usaha wajib membayarkan ganti rugi dalam bentuk pengembalian uang, penggantian barang, perawatan kesehatan, dan pemberian santunan sesuai kerugian konsumen yang dirugikan. Pembayaran ganti rugi tersebut haru dibayarkan 7 hari sesudah transaksi.

> Sanksi Pidana : Dalam sanksi pidana pelaku usaha akan dikenai hukuman kurungan 5 tahun dan denda $\mathrm{Rp}$ 2.000.000.000,00 (dua milyar rupiah) apabila melanggar Pasal 8, Pasal 9, Pasal 10, Pasal 13 ayat 2, Pasal 15, Pasal 17 ayat 1 huruf a, b, c, dan e dan Pasal 18. Serta dapat dikenakan penjara 2 tahun dan denda Rp 500.000.000,00 (lima ratus juta rupiah).

Sanksi-sanksi tersebut akan memberikan pelajaran dan efek jera bagi pelaku usaha yang tidak mematuhi segala aturan sudah ditetapkan dan melindungi konsumen yang dirugikan.

\section{SARAN}

1. Sebelum pelaku usaha menerima barang yang akan dicuci, sebaiknya barang-barang tersebut diteliti dan dilihat terlebih dahulu supaya tidak menimbulkan fitnah atau kesalah pahaman dengan konsumen.

2. Apabila pelaku usaha menemukan benda yang berharga milik konsumen, pelaku usaha wajib menghubungi atau menyimpan benda tersebut hingga konsumen datang untuk mengambilnya.

3. Pelaku usaha wajib memberi pelayanan yang baik dan ramah, agar konsumen senang untuk datang kembali.

\section{DAFTAR PUSTAKA}

Ahmadi Miru, Hukum Perlindungan Konsumen, PT. Raja Grafindo Persada, Jakarta, 2004.

R. Subekti, Aspek-Aspek Hukum Perikatan Nasional, Alumni, Bandung, 1986.

Undang-Undang Nomor 8 Tahun 1999 tentang Perlindungan Konsumen

Undang-Undang Nomor 7 Tahun 2014 tentang Perdagangan

Kitab Undang-Undang Hukum Perdata

Kitab Undang-Undang Hukum Pidana

http://rulhome.blog.com/2010/04/11/contohmetode-penelitian-normatif-denganpenelitian-empiris/ diakses tanggal 28 Juni 2014

http://eprints.umk.ac.id/333/3/BAB_II.pdf diakses tanggal 11 Juni 2014

http://perlindungankonsumenkotamalang.blo gspot.com/ diakses tanggal 8 Juni 2014

https://www.blogger.com/profile/072928420 $\underline{88812107741}$ diakses tanggal 8 Juni 2014

http://triyas18.blogspot.com/2012/05/perlind ungan-konsumen.html/ diakses tanggal 12 Juni 2014

http://wardayadi.wordpress.com/ diakses tanggal 14 Juni 2014

http://nuiysavira.blogspot.com/diakses tanggal17 Juni 2014. 